\title{
Betulinic acid augments the inhibitory effects of vincristine on growth and lung metastasis of BI6FIO melanoma cells in mice
}

\author{
N Sawada',2, K Kataoka ${ }^{2}$, K Kondo', H Arimochi', H Fujino', Y Takahashi', T Miyoshi', T Kuwahara', \\ Y Monden' and Y Ohnishi',2
}

'Department of Oncological and Regenerative Surgery, School of Medicine, The University of Tokushima, Tokushima 770-8503, Japan; ${ }^{2}$ Department of Molecular Bacteriology, Graduate School of Medicine, The University of Tokushima, Tokushima 770-8503, Japan

\begin{abstract}
We examined the antitumour effect of a combination of betulinic acid (BA) and vincristine (VCR) on murine melanoma BI6FI0 cells in vitro and in vivo. Betulinic acid, a pentacyclic triterpene, showed a synergistic cytotoxic effect on melanoma cells by combinational use of VCR. Betulinic acid and VCR induced cell cycle arrest at different points (BA at GI phase and VCR at G2/M phase) and caused apoptosis in BI6FIO melanoma cells. In the in vivo study, VCR inhibited metastasis of tumour cells to the lung. The addition of BA to VCR augmented suppression of the experimental lung metastasis of melanoma cells in C57BL/6 mice. The number of lung nodules of more than I mm in diameter in mice treated with BA and VCR was less than that in mice treated with VCR alone. These results suggest that BA is an effective supplement for enhancing the chemotherapeutic effect on malignant melanoma.

British Journal of Cancer (2004) 90, 1672-1678. doi:10.1038/sj.bjc.660I746 www.bjcancer.com

Published online 23 March 2004

(c) 2004 Cancer Research UK
\end{abstract}

Keywords: synergistic antitumour effect; betulinic acid; vincristine; cell cycle arrest; GI phase

When multiple metastases are found at the time of clinical diagnosis, surgical operations are usually not performed, and the patients are treated mainly by radiotherapy or chemotherapy with various anticancer drugs. To investigate the effects of anticancer drugs on tumour cells and their lung metastasis, the experimental lung metastasis model by Fidler and Kripke (1977) has been used (Miyoshi et al, 2000). Although anticancer drugs are widely used for cancer therapy, a sufficient quantity of the drug for treatment cannot be administered in many cases due to severe side effects.

Malignant melanoma is difficult to cure. Since melanoma cells have the ability to spread to distal organs, various anticancer drugs have been used in combination to try to improve the therapeutic effect on malignant melanoma. For example, lovastatin has been shown to potentiate the antitumour activity of doxorubicin in murine melanoma (Feleszko et al, 2002), and exisulind in combination with docetaxel has been shown to inhibit the growth and metastasis of human lung cancer (Chan et al, 2002). Recently, the antitumour effect of combinational therapy using an anticancer drug and a phytochemical has been studied (Darzynkiewicz, 1995; Christensen and LeBlanc, 1996; Singh et al, 2002). Phytochemicals such as flavonoid have relatively low levels of toxicity (Singh et al, 2002) and can induce apoptosis or cell cycle arrest in tumourderived cells (Darzynkiewicz, 1995). We previously reported that an extract of a medicinal plant lemon grass containing various phytochemicals inhibited the formation of azoxymethane-induced DNA adducts and aberrant crypt foci in the rat colon (Suaeyun et al, 1997).

*Correspondence: Dr Y Ohnishi;

E-mail address: ohnishi@basic.med.tokushima-u.ac.jp

Received 13 November 2003; revised 3 February 2004; accepted 3 February 2004; published online 23 March 2004
Betulinic acid (BA), a pentacyclic triterpene isolated from the root bark of Morus australis or Clerodendrum mandarinorum and many other medicinal plants (Zhu et al, 1996; Ko et al, 1997), has recently been reported to have cytotoxic activity against several tumour cell lines (Pisha et al, 1995; Fulda et al, 1997, 1998; Wick et al, 1999; Kwon et al, 2002; Wachsberger et al, 2002). Betulinic acid is a novel experimental antineoplastic agent for human melanoma cells in vitro (Pisha et al, 1995; Wachsberger et al, 2002). Betulinic acid also induces apoptosis in neuroectodermal tumour and glioma cells (Fulda et al, 1997, 1998; Wick et al, 1999). Furthermore, BA has been shown to inhibit growth factor-induced angiogenesis in vitro (Kwon et al, 2002).

Vincristine (VCR) is one of the major chemotherapeutic agents used for the treatment for malignant melanoma. Vincristine showed antitumour effects on B16 melanoma cells, but a high dose of VCR induces severe bone marrow toxicity (Morrow et al, 1987). In this study, we evaluated the effectiveness of combination therapy with VCR and BA for malignant melanoma by examining the synergistic cytotoxic activity against B16F10 melanoma cells in vitro and in vivo.

\section{MATERIALS AND METHODS}

\section{Chemicals}

Betulinic acid, VCR, annexin V-FITC and propidium iodide (PI) solution was obtained from Wako Pure Chemical Industries, Ltd, Osaka, Japan. Triton X-100, proteinase K, agarose and boric acid were obtained from Sigma Chemical Co., St Louis, MO, USA. Betulinic acid and VCR were dissolved in dimethyl sulphoxide (DMSO) and saline, respectively. They were diluted with saline to appropriate concentrations and stored in a refrigerator at $4{ }^{\circ} \mathrm{C}$ until use. 


\section{Animal model}

Female C57BL/6 mice (9-10 weeks old) obtained from SLC Japan (Hamamatsu, Japan) were housed in plastic cages with sawdust bedding and given food and water ad libitum. The room in which the mice were kept, in the Institute of Animal Experimentation, School of Medicine, The University of Tokushima, Japan, was environmentally controlled at a temperature of $23 \pm 2{ }^{\circ} \mathrm{C}$ and humidity of $55 \pm 10 \%$ and with a 13-h light/11-h dark cycle. All animal experiments were carried out with approval by the Institutional Animal Care and Use Committee of the University of Tokushima School of Medicine, and met the standards required by the United Kingdom Coordinating Committee on Cancer Research (UKCCCR) guidelines (Workman et al, 1998).

\section{Cell culture conditions}

B16F10 melanoma cells were purchased from the American Type Culture Collection (Virginia, USA) and were maintained in DMEM medium (Nissui Pharmaceutical Co., Japan) supplemented with $5 \%$ calf serum (Gibco Co., NY, USA), 5\% horse serum (Gibco), penicillin-streptomycin mix (Gibco) and gentamycin (Gibco). B16F10 melanoma cells were passaged every 3-4 days.

\section{Annexin V-based apoptosis analysis}

B16F10 melanoma cells $\left(1 \times 10^{5}\right)$ were cultured in $25 \mathrm{~cm}^{2}$ tissue culture plates for $24 \mathrm{~h}$ before the treatment with test reagents. Betulinic acid at concentrations of $1,2.5$ and $5 \mu \mathrm{M}$ or VCR at a concentration of $1 \mathrm{nM}$ was added, and the cells were incubated for a further $24 \mathrm{~h}$. After the incubation, the cells were trypsinised, washed with phosphate-buffered saline (PBS), and suspended in $1 \mathrm{ml}$ of a calcium-containing binding buffer. Then $5 \mu \mathrm{l}$ of annexin V-FITC and $5 \mu \mathrm{l}$ of PI were added to the cell suspensions. After 10 -min incubation at room temperature, early apoptotic cells (annexin V positive and PI negative) and late apoptotic/necrotic cells (annexin V positive and PI positive) as well as living cells (annexin V negative and PI negative) were detected by a flow cytometer (Coulter Epics XL-MCL, Beckman Coulter, Tokyo, Japan). The data were analysed using CellQuest software. The early and late apoptotic cells (annexin $\mathrm{V}$ positive) were defined as the apoptotic population.

\section{DNA fragmentation-based apoptosis analysis}

Total DNA was extracted according to the method of Lee and Shacter (1999). Briefly, B16F10 melanoma cells $\left(2 \times 10^{6}\right)$ were cultured in $60 \mathrm{~cm}^{2}$ tissue culture plates for $24 \mathrm{~h}$ before the treatment with test reagents. Betulinic acid at concentrations of $1,2.5$ and $5 \mu \mathrm{M}$ was added, and the cells were incubated for a further $24 \mathrm{~h}$. Cells were harvested, washed with PBS and lysed in buffer containing $10 \mathrm{~mm}$ Tris- $\mathrm{HCl}(\mathrm{pH} 7.8), 10 \mathrm{~mm}$ EDTA, $0.5 \%$ Triton X-100, $200 \mu \mathrm{g} \mathrm{ml}^{-1} \mathrm{RNaseA}$ and $200 \mu \mathrm{g} \mathrm{ml}^{-1}$ proteinase $\mathrm{K}$. After DNA was precipitated with isopropanol, it was then resuspended in a Tris-EDTA solution. Samples were resolved by electrophoresis on $2 \%$ agarose gels and visualised by ethidium bromide staining and UV transillumination.

\section{Cell cycle distribution analysis}

The effect of BA or VCR on cell cycle distribution in vitro was determined by using a flow cytometer. B16F10 melanoma cells $\left(1 \times 10^{6}\right)$ were cultured in $25 \mathrm{~cm}^{2}$ tissue culture plates for $24 \mathrm{~h}$ before the treatment with test reagents. After 24 or $36 \mathrm{~h}$ of incubation with BA at concentrations of $1,2.5$ and $5 \mu \mathrm{M}$ or VCR at a concentration of $1 \mathrm{nM}, \mathrm{B} 16 \mathrm{~F} 10$ melanoma cells were fixed with 99\% ethanol, treated with RNaseA and stained with PI solution containing RNase A. A flow cytometer was used to determine the percentages of cells in G0/G1, S and G2/M phases of the cell cycle.

\section{MTS assay}

The standard MTS (3-(4,5-dimethylthiazol-2-yl)-5-(3-carboxymethoxyphenyl)-2-(4-sulphophenyl)-2H-tetrazolium, innersalt solution) (Takara Co., Kusatsu, Japan) assay was performed to examine cytostatic/cytotoxic effects of BA and/or VCR on B16F10 melanoma cells according to the manufacturer's instructions. Briefly, tumour cells $\left(5 \times 10^{3}\right.$ cells $)$ were seeded in 96-well microtiter plates (Becton Dickinson Co., Franklin Lakes, NJ, USA). After an overnight incubation at $37^{\circ} \mathrm{C}$ in $5 \% \mathrm{CO}_{2}$, serially diluted solutions of BA, VCR or both were added in triplicate to a final volume of $200 \mu \mathrm{l}$. After incubation for $24 \mathrm{~h}$, the medium was removed, and the cells were washed twice with culture medium and resuspended in $200 \mu \mathrm{l}$ of culture medium. Then, $20 \mu \mathrm{l}$ of MTS was added to each well, and the plates were incubated at $37^{\circ} \mathrm{C}$ for $1 \mathrm{~h}$. The absorbance of each well was read at $450 \mathrm{~nm}$ on a microplate reader (microplate reader: MTP-120, Corona Co., Katsuta, Japan). The relative viability was calculated as follows: relative viability $=[$ (experimental absorbance - background absorbance $) \div$ (absorbance of untreated controls-background absorbance) $] \times 100 \%$.

\section{Drug interaction analysis}

Synergistic interaction between BA and VCR was determined by using isobologram analysis as described in detail previously (Berenbaum, 1981; Sora et al, 1994). Briefly, inhibition of cell proliferation was determined as described above. Equieffective concentrations were used for the analysis. The interaction index for the two-drug combination was computed by the following equation: interaction index $=\mathrm{BA} c / \mathrm{BA} e+\mathrm{VCR} c / \mathrm{VCR} e$, where $\mathrm{BA} e$ and $\mathrm{VCR} e$ are concentrations of $\mathrm{BA}$ and $\mathrm{VCR}$, respectively, that inhibit cell proliferation to $40 \%$ of the control level when used alone, and BAc and $\mathrm{VCR} c$ are concentrations of BA and VCR, respectively, that produce the same effect when used in combination. According to this method, an interaction index of less than 1.0 indicates synergistic interaction between two drugs. An interaction index of more than 1.0 indicates antagonism, and an index of 1.0 indicates additive interaction.

\section{Effects of BA and VCR and their combination on tumour development in C57BL/6 mice injected with B16F10 melanoma cells}

On day 0 , B16F10 melanoma cells $\left(1 \times 10^{5}\right.$ cells $/ 0.1 \mathrm{ml}$ medium $)$ were injected into the tail veins of anaesthetised 9- to 10 -week-old female C57BL/6 mice. Tumour-bearing mice were divided into four groups (five mice in each group) and treated intraperitoneally (i.p.) with saline $(0.1 \mathrm{ml}), \mathrm{BA}\left(10 \mathrm{mg} \mathrm{kg}^{-1} \mathrm{day}^{-1}\right)$, VCR $\left(0.065 \mathrm{mg} \mathrm{kg}^{-1} \mathrm{day}^{-1}\right)$ or a combination of both drugs (BA, $10 \mathrm{mg} \mathrm{kg}^{-1} \mathrm{day}^{-1}$; VCR, $0.065 \mathrm{mg} \mathrm{kg}^{-1} \mathrm{day}^{-1}$ ) (Figure 1). The dose of $\mathrm{BA}$ for the treatment of mice was decided by referring to a previous report (Pisha et al, 1995). Body weights of mice were recorded every 4 days to determine whether the treatment influenced health status. The mice were killed by cervical dislocation under anaesthesia with diethyl ether 17 days after inoculation of tumour cells. The lungs were removed, and two independent observers determined the numbers and sizes of lung metastatic nodules.

\section{Data analysis}

All data were statistically analysed by analysis of variance. $P<0.05$ was considered to be statistically significant. 


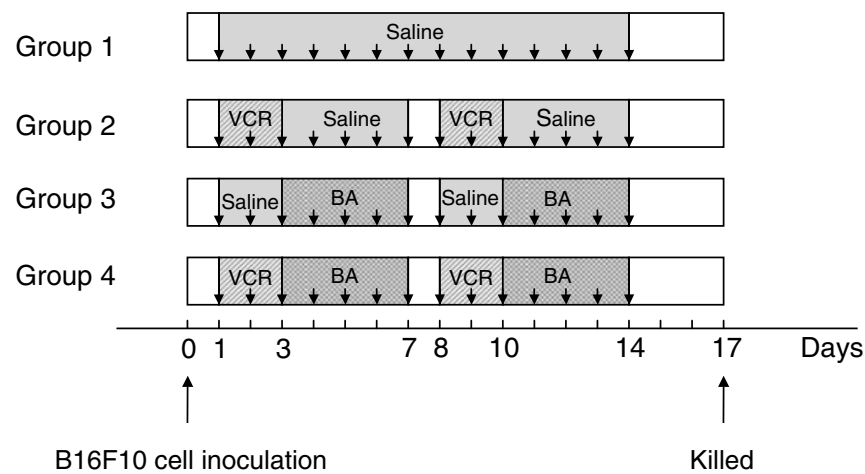

Figure I Experimental protocol for animal experiment. Arrows indicate the series of injection of saline, BA (BA, i.p., $10 \mathrm{mg} \mathrm{kg}^{-1}$ ) or VCR (VCR, i.p., $0.065 \mathrm{mg} \mathrm{kg}^{-1}$ ). Mice in groups I, 2 and 3 were administered saline, VCR and BA, respectively. Mice in group 4 were administered both VCR and BA.

\section{RESULTS}

Effects of VCR and/or BA on the growth of B16F10 melanoma cells in vitro

Vincristine is one of the major chemotherapeutic agents for patients with malignant melanoma. To determine whether treatment with a combination of VCR and BA has a greater inhibitory effect than does treatment with VCR or BA alone, we examined the inhibitory effects of VCR alone, BA alone and the combination of them using MTS assays. When the growth level of untreated cells was regarded as $100 \%$, the growth levels of cells treated with $0.1,1$ and $10 \mathrm{nM}$ VCR were 83.4, 71.2 and $56.2 \%$, respectively (Figure 2). Vincristine inhibited the growth of B16F10 cells in a dosedependent manner. In addition, BA also inhibited the growth of B16F10 cells in a dose-dependent manner $(1 \mu \mathrm{M}, 92.5 \% ; 2.5 \mu \mathrm{M}$, $91.9 \% ; 5 \mu \mathrm{M}, 62.0 \%$ ). Combinational treatment with 1 or $10 \mathrm{nM}$ VCR and BA resulted in the inhibition of the growth of B16F10 cells in a dose-dependent manner. The combination of $10 \mathrm{nM}$ VCR and $5 \mu \mathrm{M} \mathrm{BA}$ greatly inhibited the growth of cells (12.9\%).

\section{Induction of apoptosis in B16F10 cells by VCR and BA}

B16F10 melanoma cells were incubated in DMEM medium with VCR at $1 \mathrm{nM}$ or BA at three different concentrations $(1,2.5$ and $5 \mu \mathrm{M})$ for $24 \mathrm{~h}$. The percentage of apoptotic cells was determined as described in Materials and methods. The apoptotic population of untreated cells was $6.1 \%$, while that of cells treated with $1 \mathrm{nM}$ VCR was $25.2 \%$ (Figure 3). The apoptotic populations of cells treated with $1,2.5$ and $5 \mu \mathrm{M} \mathrm{BA}$ alone were $8.9,15.2$ and $19.5 \%$, respectively. Moreover, the induction of apoptosis was evaluated by DNA fragmentation (Wyllie, 1980). DNA ladder formation was detected (Figure 4), and the fragments were stained in a dosedependent manner. These findings indicate that BA induced apoptosis in a dose-dependent manner.

\section{Determination of the synergistic effect of VCR and BA using isobologram analysis}

To clarify the synergistic effect of VCR and BA on inhibition of the growth of B16F10 cells, we used isobologram analysis by the method of Berenbaum (1981). Treatment with VCR or BA resulted in inhibition of the growth of B16F10 cells in a dose-dependent manner (Figure $5 \mathrm{a}$ and $\mathrm{b})$. The inhibitory concentration $\left(\mathrm{IC}_{40}\right)$ of VCR alone and that of BA alone showing $40 \%$ of the control growth level were $100 \mathrm{~nm}$ and $10 \mu \mathrm{M}$, respectively (Figure $5 \mathrm{a}$ and b). When $\mathrm{IC}_{40}$ was determined by combinational use of both drugs, a combination of $10 \mathrm{~nm}$ VCR and $1.8 \mu \mathrm{M} \mathrm{BA}$, and a combination of

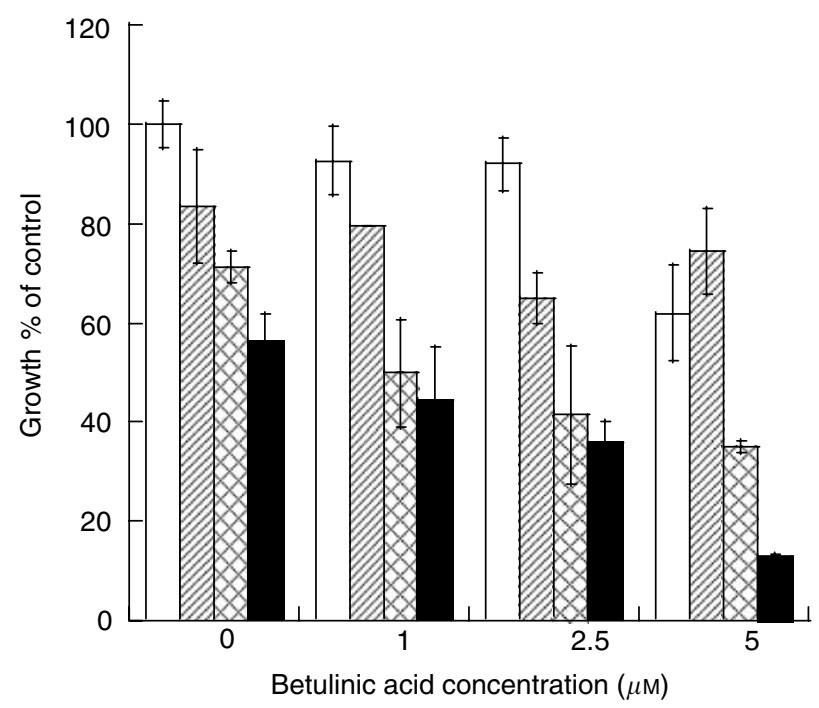

Figure 2 Effects of VCR and/or BA on the growth of BI6FIO cells. Concentrations of VCR were O nM (open box), 0.1 nM (hatched box), I.0 nM (latticed box) and I0 nM (closed box). Cytostatic/cytotoxic effects were tested by MTS assays and expressed as the percentage of the control growth (\% of untreated control). Bars, mean \pm s.d.

$1 \mathrm{nM}$ VCR and $3 \mu \mathrm{M}$ BA showed $40 \%$ growth of the control (Figure $5 \mathrm{c}$ ). The interaction indices calculated by the equation shown in Materials and methods were 0.28 and 0.31 , which are less than 1.0 (Figure $5 \mathrm{~d}$ ). The results of isobologram analysis showed that treatment with a combination of VCR and BA synergistically inhibited the growth of B16F10 cells.

\section{Induction of G2/M arrest and G1 arrest by VCR and BA, respectively}

Cell cycle distribution analysis was performed to clarify the mechanism of synergic inhibitory action on B16F10 melanoma cells. B16F10 cells were incubated with VCR and BA for 24 or $36 \mathrm{~h}$ in the same manner as in the cell apoptosis assay. The proportions of cells in the G2/M phase that had been treated with $1 \mathrm{nM}$ VCR for 24 and $36 \mathrm{~h}$ were 29.3 and $79.8 \%$, respectively (untreated group: $14.5 \%$ after $24 \mathrm{~h}$ and $10.0 \%$ after $36 \mathrm{~h}$ ) (Table 1 ), indicating that VCR induces cell cycle arrest at the G2/M phase. The population of G0/G1 cells treated with BA for $24 \mathrm{~h}$ increased in a dose-dependent manner ( $1 \mu \mathrm{M}, 78.8 \%$; $2.5 \mu \mathrm{M}, 86.1 \%$; $5 \mu \mathrm{M}, 95.5 \%)$. Moreover, the cell population in the G0/G1 phase after $36 \mathrm{~h}$ of treatment was constant (93\%) regardless of the concentration (untreated group: $80 \%$ ), indicating that BA induces cell cycle arrest at the G1 phase. These results demonstrated that VCR and BA induce cell cycle arrest at different stages.

\section{Antimetastatic effects of VCR, BA and their combination in C57BL/6 mice treated with B16F10 melanoma cells}

To determine whether the augmenting effect of BA on the cytotoxicity of VCR against B16F10 melanoma cells can be reproduced in vivo, animal experiments were performed according to the schedule shown in Figure 1. B16F10 cells formed $50.2 \pm 20.7$ nodules in the lung in the nontreatment group, whereas they formed $28.0 \pm 5.4,35.6 \pm 18.8$ and $12.4 \pm 9.5$ nodules in the VCR, $\mathrm{BA}$ and combinational administration groups, respectively (Figure 6). Treatment with VCR $\left(0.065 \mathrm{mg} \mathrm{kg}^{-1}\right.$ day $\left.^{-1}\right)$ alone or in combination with BA $\left(10 \mathrm{mg} \mathrm{kg}^{-1} \mathrm{day}^{-1}\right)$ significantly suppressed the experimental metastasis. B16F10 melanoma cells formed $36.0 \pm 12.2$ large nodules of more than $1 \mathrm{~mm}$ in diameter 


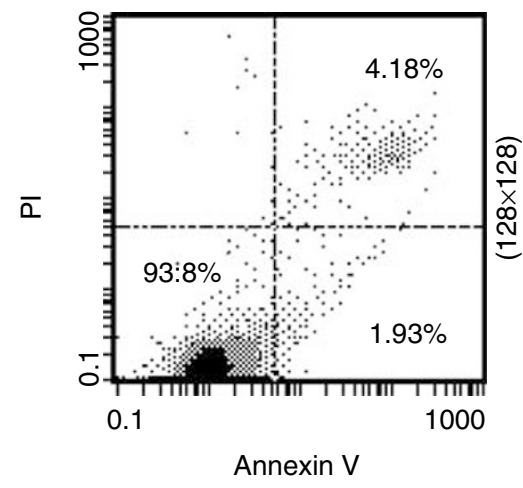

Nontreatment

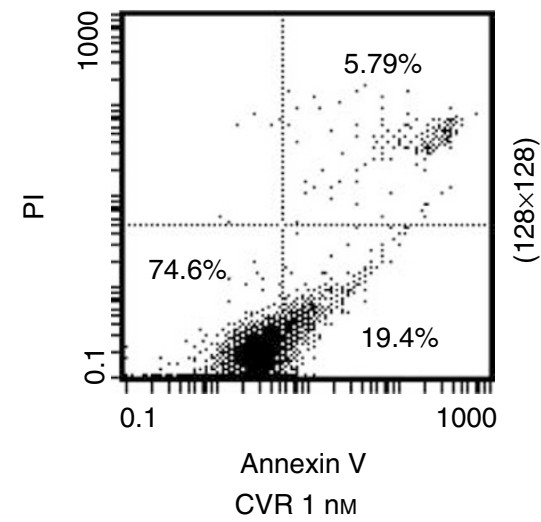

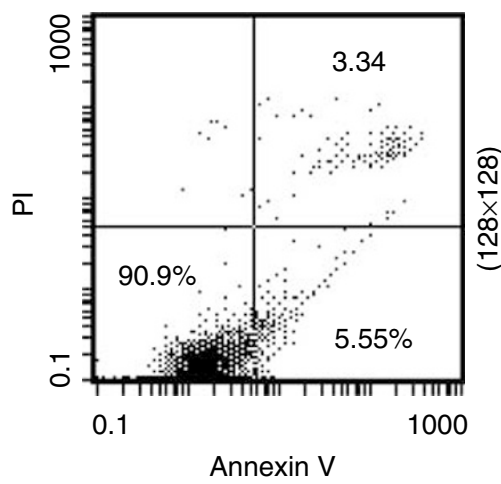

BA $1 \mu \mathrm{M}$

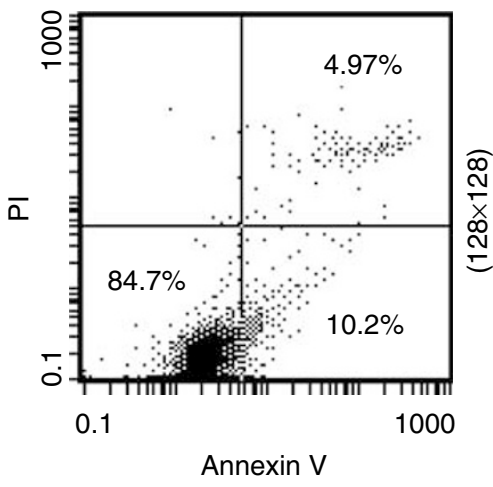

BA $2.5 \mu \mathrm{m}$

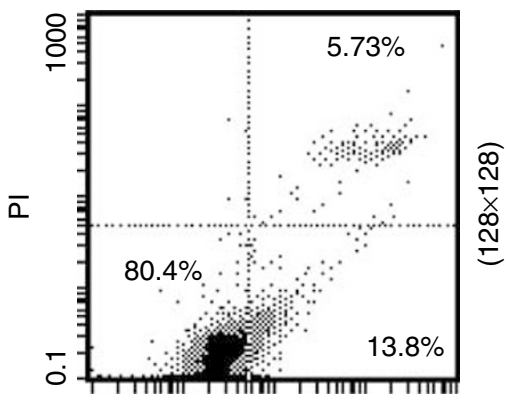

0.1

1000

Annexin V

BA $5 \mu \mathrm{m}$

Figure 3 Apoptosis assay of BI6FIO cells treated with VCR or BA. Flow cytometric analysis of apoptosis in BI6FIO cells was performed by treatment with VCR (I nM) and BA (I, 2.5 or $5 \mu \mathrm{M})$ for $24 \mathrm{~h}$ and by staining with annexin $\mathrm{V}$-FITC and PI.

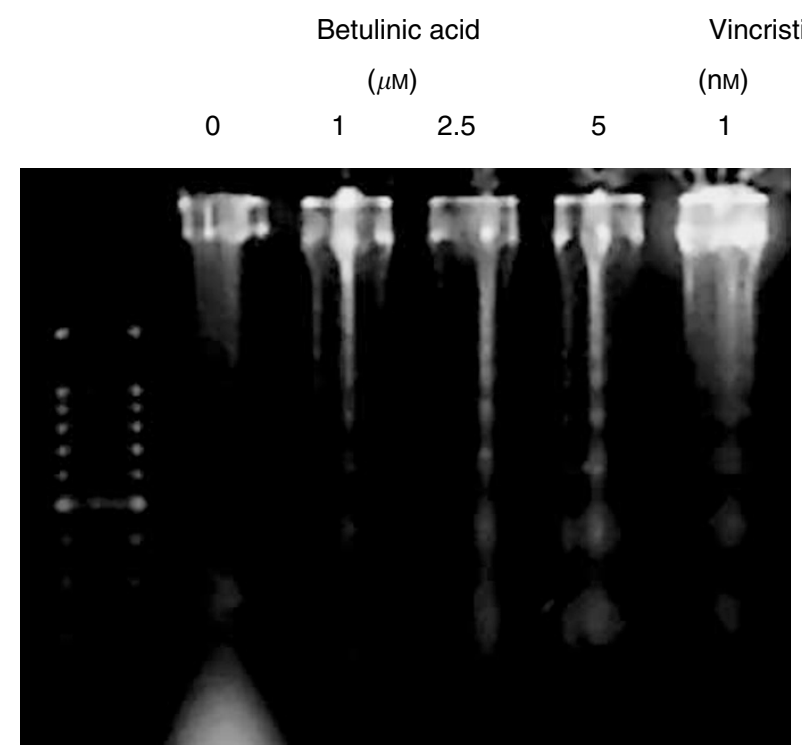

Figure 4 DNA fragmentation analysis of apoptosis in BI6FIO cells treated with BA.

in the lung in the nontreatment group, whereas they formed $14.0 \pm 2.0,16.8 \pm 9.0$ and $3.6 \pm 5.5$ large nodules in the VCR, BA and combinational administration groups, respectively. The ratios of the number of large nodules to total metastatic nodules in the lung in the nontreatment group and the VCR, BA and combinational administration groups were 71.7, 50.0, 47.2 and $29.0 \%$, respectively, indicating that combinational treatment with VCR and BA significantly suppresses the growth of B16F10 melanoma cells after their colonisation in the lung. No weight loss was observed in any mice treated with VCR, BA or both reagents (data not shown).

\section{DISCUSSION}

In most cases of malignant melanoma, distant metastasis is found at the time of clinical diagnosis. It has been reported that the median survival time of stage IV melanoma patients is about $6-7.5$ months, the 5-year survival rate being approximately $6 \%$ (Bajetta et al, 2002). Lung metastasis of melanoma cells from primary lesions is an especially important factor influencing the prognosis of patients. Therefore, the main treatment for malignant melanoma is various chemotherapeutic agents. Various anticancer drugs, including bleomycin, VCR, lomustine and dacarbazine, have been used in recent years for treating patients with melanoma (Wöll et al, 1999; Kivela et al, 2003). However, severe side effects of the chemotherapeutic agents have limited the application of high-dose chemotherapy or combination therapy with different anticancer drugs for many cases of malignant melanoma (Bajetta et al, 2002).

Combinational treatment with different drugs that induce different cell cycle arrest results in apoptosis in tumour cells (Darzynkiewicz, 1986; Bhuyan and Groppi, 1989; Ko et al, 1997). It was thought that treatment with the combination of BA and VCR had a synergistic cytotoxic effect on tumour cells because treatment with BA alone and treatment with VCR alone induced 

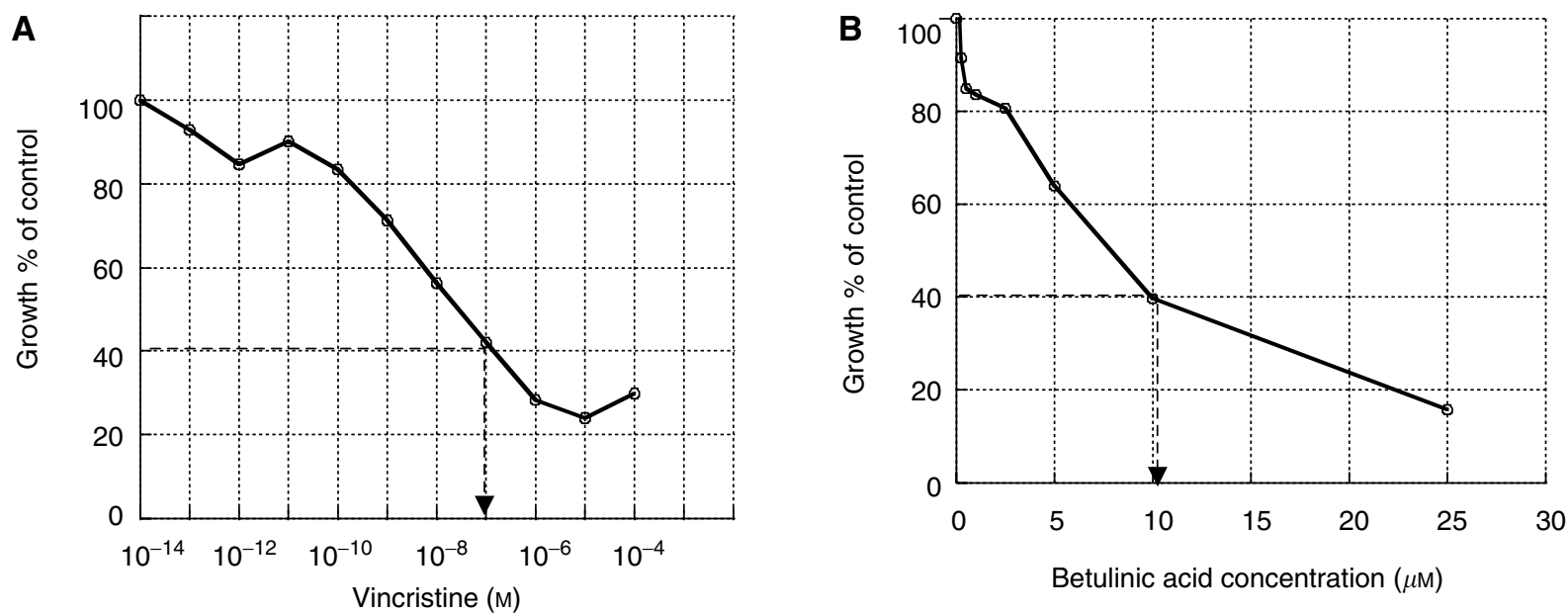

C
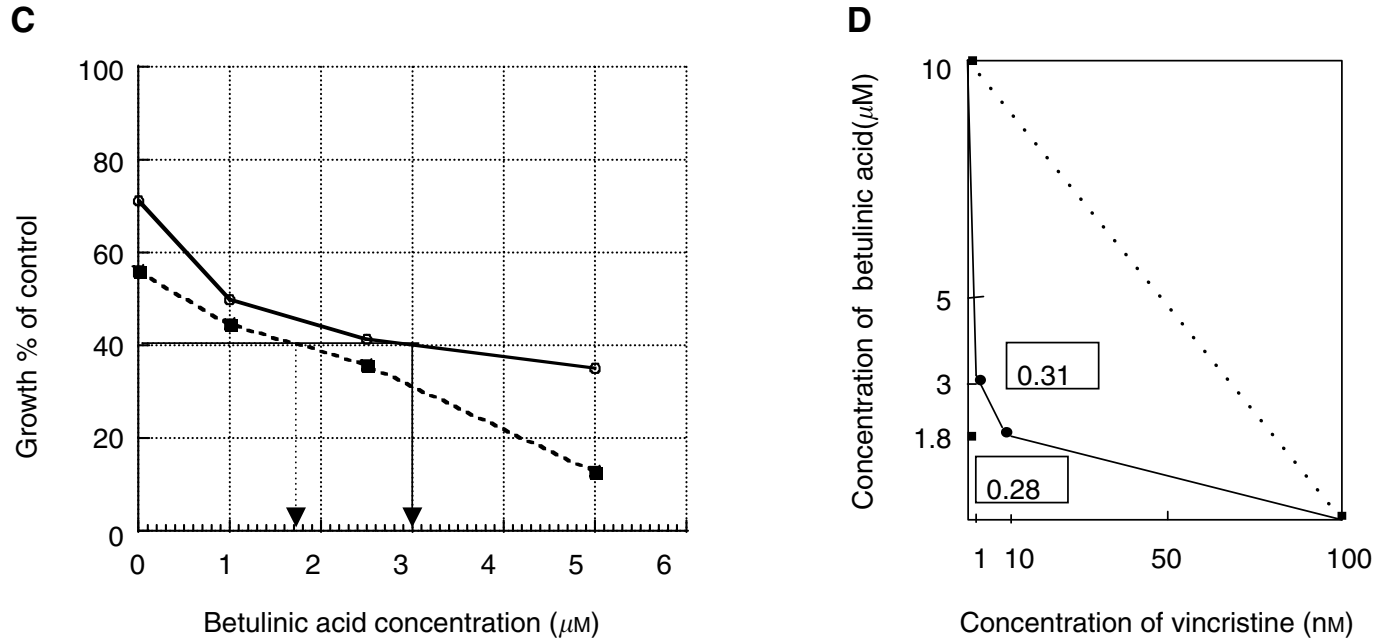

Concentration of vincristine $(\mathrm{nM})$

Figure 5 Effects of VCR and/or BA on the growth of BI6FIO cells. Cytostatic/cytotoxic effects were tested by MTS assays and expressed as the percentage of the control growth $(\mathbf{A}-\mathbf{C})$. Solid and dotted lines show I and $10 \mathrm{nM}$ VCR, respectively $(\mathbf{C})$. The isobologram depicts the interaction between $\mathrm{BA}$ and VCR in inhibiting the growth of BI6FIO cells (D). The solid line shows concentrations of both drugs required to inhibit cell growth to $40 \%$ (IC 40 ). The dotted line shows concentrations of drugs required to produce the same degree of growth inhibition as that in the case of interactions being additive. The numbers in boxes are interaction indices.

Table I Cell cycle distribution of BI6FIO cells treated with VCR or BA

\begin{tabular}{|c|c|c|c|c|c|c|}
\hline \multirow[b]{3}{*}{ Treatment } & \multicolumn{6}{|c|}{ Cell cycle distribution (\%) } \\
\hline & \multicolumn{2}{|c|}{$\mathbf{G O} / \mathbf{G I}^{\mathbf{a}}$} & \multicolumn{2}{|c|}{$\mathbf{S}^{\mathbf{a}}$} & \multicolumn{2}{|c|}{$\mathbf{G} 2 / \mathbf{M}^{\mathrm{a}}$} \\
\hline & $24 h^{b}$ & $36 h^{b}$ & $24 h^{b}$ & $36 h^{b}$ & $24 h^{b}$ & $36 h^{b}$ \\
\hline None & 74.1 & 80.7 & 11.4 & 9.3 & 14.5 & 10.0 \\
\hline VCR (I nM) & 62.7 & 20.2 & 8.0 & 0.0 & 29.3 & 79.8 \\
\hline $\mathrm{BA}(\mid \mu \mathrm{M})$ & 78.8 & 93.3 & 2.0 & 5.6 & 19.2 & 1.1 \\
\hline $\mathrm{BA}(2.5 \mu \mathrm{M})$ & 86.1 & 93.1 & 3.0 & 2.1 & 10.9 & 4.8 \\
\hline $\mathrm{BA}(5 \mu \mathrm{M})$ & 95.5 & 93.4 & 0.0 & 2.2 & 4.4 & 4.4 \\
\hline
\end{tabular}

$\mathrm{VCR}=$ vincristine; $\mathrm{BA}=$ betulinic acid. ${ }^{\mathrm{a} C e l l}$ cycle phase. ${ }^{\mathrm{b}}$ Incubation time.

cell cycle arrest in different phases. Although BA did not induce cell cycle arrest in glioma cells (Wick et al, 1999), we found that BA induced the accumulation of B16F10 melanoma cells in the G1 phase after $24 \mathrm{~h}$ of coincubation in a dose-dependent manner. Moreover, BA induced the accumulation of $93 \%$ of B16F10 cells in the G1 phase after $36 \mathrm{~h}$ of coincubation. It is expected that elucidation of the mechanism by which BA inhibits the growth of B16F10 melanoma cells will lead to the establishment of effective combinational regimens with other antitumour drugs with

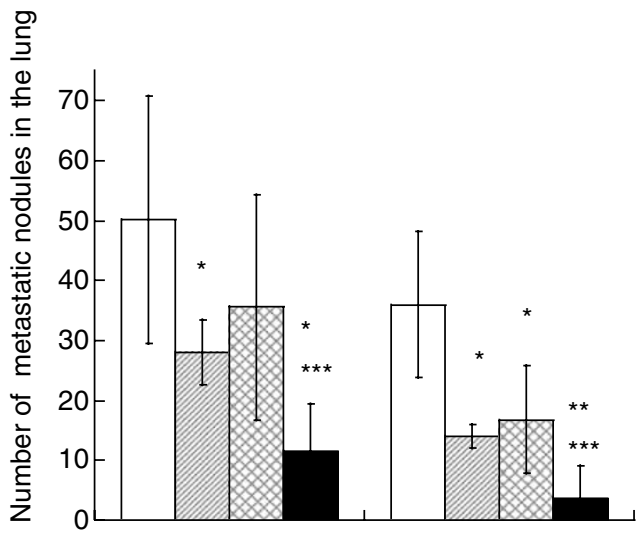

All metastatic nodules Metastatic nodules of more than $1 \mathrm{~mm}$

Figure 6 Effects of VCR and/or BA on experimental metastasis in mice. Mice were treated with a solvent (open box), $0.065 \mathrm{mg} \mathrm{kg}^{-1}$ VCR (hatched box), $10 \mathrm{mg} \mathrm{kg}^{-1}$ BA (latticed box), and both drugs (closed box) as described in Materials and methods. The numbers of tumour nodules were evaluated with classification by size (all sizes and more than $1 \mathrm{~mm}$ in diameter). ****significantly different from the control group $(P<0.05$ and $P<0.0001)$. *** Significantly different from the VCR group and the BA group $(P<0.05)$ 
different cytotoxic mechanisms for the treatment of malignant melanoma. It has been reported that BA enhanced the levels of BAX and BCL-2 proteins in glioma cells and induced apoptosis in those cells (Wick et al, 1999). BA induces apoptosis via the activation of caspases in neuroectodermal cells (Fulda et al, 1997). However, the mechanism by which apoptosis is induced in B16F10 cells by BA remains to be determined. Cell arrest, damage to DNA or stress to the cytoplasm or cell membrane may be the cause of apoptosis (Aller et al, 1992; Gohen et al, 1992; Ko et al, 1997). We believe that results of analysis of cell cycle distributions or apoptotic pathways to determine mechanisms of cytotoxicity of other chemotherapeutic agents used in the treatment for malignant melanoma will open the gate for the establishment of effective combinational therapeutic regimens against the still untreatable malignant disease using BA.

We performed animal experiments to determine whether BA and VCR show a suppressive effect on the growth or metastatic state of B16F10 melanoma cells in vivo. Antimetastatic activity was investigated by counting lung metastatic nodules as reported previously (Jani et al, 1993; Kang et al, 2000; Feleszko et al, 2002), because B16F10 melanoma cells preferentially induce lung metastasis (Jani et al, 1993; Gude et al, 2001; Malafa et al, 2002). Although treatment with VCR alone resulted in a significant suppression of metastasis of melanoma cells to the lung, the additional use of BA resulted in greater suppression than that in the case of treatment with VCR alone. Treatment with a combination of VCR and BA resulted in a significant reduction in the numbers of lung nodules of more than $1 \mathrm{~mm}$ in diameter in mice compared with that in the case of treatment with VCR or BA alone. These results suggest that BA potentiates the antitumour

\section{REFERENCES}

Aller P, Rius C, Mata F, Zorilla A, Cabanas C, Bellon T, Barnabeu C (1992) Camptothecin induces differentiation and stimulates the expression of differentiation-related genes in U-937 promonocytic leukemia cells. Cancer Res 52: 1245 - 1251

Bajetta E, Vecchio MD, Marty CB, Vitali M, Buzzoni R, Rixe O, Nova P, Aglione S, Taillibert S, Khayat D (2002) Metastatic melanoma: chemotherapy. Semin Oncol 29: 427-445

Berenbaum MC (1981) Criteria for analyzing interactions between biologically active agents. Adv Cancer Res 35: 269-336

Bhuyan BK, Groppi VE (1989) Cell cycle specific inhibitors. Pharmacol Ther 42: $307-348$

Chan DC, Earle KA, Zhao TLM, Helfrich B, Zeng C, Baron A, Whitehead CM, Piazza G, Pamukcu R, Thompson WJ, Alila H, Nelson P, Bunn Jr PA (2002) Exisulind in combination with docetaxel inhibits growth and metastasis of human lung cancer and prolongs survival in athymic nude rats with orthotopic lung tumors. Clin Cancer Res 8: 904-912

Christensen JG, LeBlanc GA (1996) Reversal of multidrug resistance in vivo by dietary administration of the phytochemical indole-3-carbinor. Cancer Res 56: $574-581$

Darzynkiewicz Z (1986) Cell growth and division cycle. In Cell Cycle Effects of Drugs, Dethlefsen L (ed) pp. 1-43. New York: Pergamon Press

Darzynkiewicz Z (1995) Apoptosis in antitumor strategies: modulation of cell cycle or differentiation. J Cell Biochem 58: 151-159

Feleszko W, Mlynarczuk I, Olszewska D, Jalili A, Stoklosa T, Lasek W, Hoser G, Korczak-Kowalska G, Jakobisiak M (2002) Lovastatin potentiates antitumor activity of doxorubicin in murine melanoma via an apoptosis-dependent mechanism. Int J Cancer 100: 111-118

Fidler J, Kripke L (1977) Metastasis results from preexisting variant cells within a malignant tumor. Science 197: 893-895

Fulda S, Friesen C, Los M, Scaffidi C, Mier W, Benedict M, Nuòez G, Krammer PH, Peter ME, Debatin KM (1997) Betulinic acid triggers CD95(apo-1/Fas)- and p53-independent apoptosis via activation of caspases in neuroectodermal tumors. Cancer Res 57: 4956-4964

Fulda S, Scaffidi C, Susin SA, Krammer PH, Kroemer G, Peter ME, Debatin KM (1998) Activation of mitochondria and release of mitochondrial apoptogenic factors by betulinic acid. J Biol Chem 273: 33942-33948 activity of VCR also in vivo. For the establishment of metastasis, tumour cells must leave the original tumour mass, invade the surrounding tissue and then enter blood vessels. The next steps are tumour cell attachment to endothelial cells in the blood vessel, invasion and growth in the target organ (Liotta, 1986; Nicolson, 1988). We could not determine which metastatic steps were mainly inhibited by the combinational treatment with BA and VCR; however, the significant reduction in the number of lung nodules of more than $1 \mathrm{~mm}$ in diameter in the combinational treatment group indicates their inhibitory effect on tumour growth after attachment to target metastatic sites. Furthermore, we observed no significant difference between weight losses in the groups treated with VCR, BA and both, indicating that the combination of BA and VCR might be an effective regime with side effects of relatively small magnitude for the treatment of malignant melanoma.

In summary, treatment with a combination of VCR and BA resulted in synergistic suppression of cell growth in vitro and in the prevention of B16F10 melanoma experimental metastasis by direct suppression of cell growth in vivo. It is expected that BA can augment antitumour activities of various drugs showing different types of cytotoxic mechanisms.

\section{ACKNOWLEDGEMENTS}

We thank Dr Yoshihito Okamura, Department of Instrument Center, The University of Tokushima for his valuable comments on cytometric analysis.
Gohen G.M, Sun X, Snowden RT, Dinsdale D, Skilleter DN (1992) Key morphological features of apoptosis may occur in the absence of internucleosomal fragmentation. Biochem $J$ 286: 331-334

Gude RP, Menon LG, Rao SG (2001) Effect of caffeine, a xanthine derivative, in the inhibition of experimental lung metastasis induced by B16F10 melanoma cells. J Exp Clin Cancer Res 20: 287-292

Jani JP, Specht S, Stemmler N, Blanock K, Singh SV, Gupta V, Katoh A (1993) Metastasis of B16F10 mouse melanoma inhibited by lovastatin, an inhibitor of cholesterol biosynthesis. Invas Metast 13: 314-324

Kang IC, Kim DS, Jang Y, Chung KH (2000) Suppressive mechanism of salmosin, a novel disintegrin in B16 melanoma cell metastasis. Biochem Biophys Res Commun 275: 169-173

Kivela T, Suciu S, Hansson J, Kruit WH, Vuoristo MS, Kloke O, Gore M, Kemppinen MH, Parvinen LM, Kumpulainen E, Humblet Y, Pyrhonen S (2003) Bleomycin, vincristine, lomustine, and dacarbazine (BOLD) in combination with recombinant interferon alpha-2b for metastatic uveal melanoma. Eur J Cancer 39: 1115-1120

Ko HH, Yu SM, Ko FN, Teng CM, Lin CN (1997) Bioactive constituents of Morus australis and Broussonetia papyrifera. J Nat Prod 60: 1008-1011

Kwon HJ, Shim JS, Kim JH, Cho HY, Yum YN, Kim SH, Yu J (2002) Betulinic acid inhibits growth factor-induced in vitro angiogenesis via the modulation of mitochondrial function in endothelial cells. Jpn J Cancer Res 93: 417-425

Lee Y, Shacter E (1999) Oxidative stress inhibits apoptosis in human lymphoma cells. J Biol Chem 274: 19792-19798

Liotta LA (1986) Tumor invasion and metastases - role of the extracellular matrix: Rhoads memorial award lecture. Cancer Res 46: 1-7

Malafa MP, Fokum FD, Mowlavi A, Abusief M, King M (2002) Vitamin E inhibits melanoma growth in mice. Surgery 131: 85-91

Miyoshi T, Kondo K, Ishikura H, Kinoshita H, Matsumori Y, Monden Y (2000) SCID mouse lymphogenous metastatic model of human lung cancer constructed using orthotopic inoculation of cancer cells. Anticancer Res 20: $161-163$

Morrow M, Wait RB, Rosenthal RA, Gamelli RL (1987) Verapamil enhances antitumor activity without increasing myeloid toxicity. Surgery 101: $63-68$ 
Nicolson GL (1988) Organ specificity of tumor metastasis: role of preferential adhesion, invasion and growth of malignant cells at specific secondary sites. Cancer Metast Rev 7: 143-188

Pisha E, Chai H, Lee IS, Chagwedera TE, Farnsworth NR, Cordell GA, Beecher CWW, Fong HHS, Kinghorn AD, Brown DM, Wani MC, Wall ME, Hieken TJ, Gupta TKD, Pezzuto JM (1995) Discovery of betulinic acid as a selective inhibitor of human melanoma that functions by induction of apoptosis. Nat Med 1: $1046-1051$

Singh RP, Dhanalakshmi S, Agarwal R (2002) Phytochemicals as cell cycle modulators. Cell Cycle 1: 156-161

Sora MK, Kruszewski AA, Stoklosa T, Czyżyk J, Lasek W, Malejczyk J, Jakóbisiak M (1994) Synergistic anti-proliferative activity of tumor necrosis factor-alpha (TNF- $\alpha$ ) and lovastatin. Arch Immunol Ther Exp 42: $269-274$

Suaeyun R, Kinouchi T, Arimochi H, Vinitketkumnuen U, Ohnishi Y (1997) Inhibitory effects of lemon grass (Cymbopogon citratus Stapf) on formation of azoxymethane-induced DNA adducts and aberrant crypt foci in the rat colon. Carcinogenesis 18: 949-955
Wachsberger PR, Burd R, Wahl ML, Leeper DB (2002) Betulinic acid sensitization of low $\mathrm{pH}$ adapted human melanoma cells to hyperthermia. Int J Hyperthertmia 18: $153-164$

Wick W, Grimmel C, Wagenknecht B, Dichgans J, Weller M (1999) Betulinic acid-induced apoptosis in glioma cells: a sequential requirement for new protein synthesis, formation of reactive oxygen species, and caspase processing. J Pharmacol Exp Ther 289: 1306-1312

Wöll E, Bedikian A, Legha SS (1999) Uveal melanoma: natural history and treatment options for metastatic disease. Melanoma Res 9: 575-581

Workman P, Twentyman P, Balkwill F, Balmain A, Chaplin D, Double J, Embleton J, Newell D, Raymond R, Stables J, Stephens T, Wallace J (1998) United Kingdom Co-ordinating Committee on Cancer Research (UKCCCR) guidelines for the welfare of animals in experimental neoplasia (Second Edition). Br J Cancer 77: 1-10

Wyllie A (1980) Glucocorticoid-induced thymocyte apoptosis is associated with endogenous endonuclease activation. Nature 284: 555-556

Zhu M, Phillipson JD, Greengrass PM, Bowery NG (1996) Chemical and biological investigation of the root bark of Clerodendrum mandarinorum. Planta Med 62: 393-396 